\title{
THE POLICY OF SOCIAL PROTECTION OF THE ELDERLY IN THE NEW UZBEKISTAN AND ITS ESSENCE
}

\author{
Frangiza Qodir Qizi Akramova \\ Director Of The Republican Boarding House For Veterans Of War And Cocktails, Uzbekistan
}

\section{ABSTRACT}

In the new Uzbekistan, care for the elderly, their social and legal support, and increased political activity were raised to the level of state policy. This article analyzes the results of the policy of social protection of the elderly for the next five years and the practical actions taken to further improve the sphere: the essence of the law, the adoption of decrees and programs and issues of their implementation. He also stressed the importance of the policy of social protection of the elderly in the new Uzbekistan.

KEYWORDS:- Old age, social protection, compulsory social security, "Nurani", "Nurani monastery", old people in need, boarding schools "Saksovat" and "Muruvvat".

\section{INTRODUCTION}

Today, about 60 percent of the state budget of the Republic of Uzbekistan is directed to the development of the social sphere. In comparison with 1991, the real incomes of the population increased by more than 12 times, salaries, pensions and social benefits increased at a significant level. Consumer goods are rapidly increasing production and meeting the demand of the population for them[1].

At the present stage of our development, attention is paid to the issues of providing the population with mandatory social guarantees of the social sphere, social protection of low-income segments of the population, as well as state support for the elderly and disabled, improving social services, developing public-private partnership in providing social services to the population.

\section{Materials AND ANALYSIS}

During 2010-2015, 12 boarding houses "Murovvat" and "Murovvat" for the elderly and pensioners were provided with a material and technical base in Uzbekistan, the living conditions of 14.6 thousand lonely elderly people, pensioners, disabled people were improved, 5.4 thousand people were provided with rehabilitation technical means and prosthetic and orthopedic products, 6.4 thousand sanatoriums for the disabled and pensioners restored their health. The total volume of medical and social assistance provided amounted to 132.2 billion rubles. sumov.

In order to further improve the social protection 
CURRENT RESEARCH JOURNAL OF PEDAGOGICS 2(9): 22-25, September

2021 DOI: https://doi.org/10.37547/pedagogics-crjp-02-09-05

ISSN 2767-3278

(C)2021 Master Journals

\section{Crossref do) 11 Google}

Accepted 15th September, 2021 \& Published 20 ${ }^{\text {th }}$ September, 2021

of the needy segments of the population in the process of updating society, state support of the Nurani Foundation, further improvement of the system of protection of only the elderly, pensioners and disabled people, ensuring its targeting, improving the level and quality of medical and social assistance provided to the elderly, people with disabilities, it also showed the need to develop fundamentally new approaches that will provide residents of districts and cities with the opportunity to use modern methods of diagnosis and treatment on the ground.

In order to further improve the state system of support for the elderly, social protection of the elderly and veterans, increase their activity, create conditions for their full participation in the socio-political life of the country, Decree of the President of the Republic of Uzbekistan "On measures to further improve the activities of the Fund for social Use of veterans of Uzbekistan" Nuroniy "dated December 28, 2016"On measures to further improve the system of state support for the elderly and disabled "[3] in order to increase the role of representatives of the older generation in the field of social security of veterans of Uzbekistan". In this decree and decision, it was decided to involve the elderly, elderly people and veterans in public activities, improve the quality of life of elderly people in the districts, support their social activity, provide social and material support to needy and lonely elderly people in cooperation with citizens ' selfgovernment bodies, provide material support to needy and lonely elderly people., for the timely detection and treatment of diseases, 2.8 million elderly citizens are provided with a comprehensive medical examination by specialized medical teams, expansion of measures for profiling diseases among elderly citizens through constant monitoring of their health by attached foster nurses, improving the quality of life and living standards of 15.5 thousand people. In this regard, it is planned to allocate 20 thousand to specialized medical centers of the republic and more than 215 thousand to medical institutions in the regions, for a total amount of 178.9 billion soums. The total amount of 207 billion soums of the material and technical base of 12 boarding schools "Sakhovat" and "Muruvvat" for the elderly and disabled in the regions was reflected in the execution of this decree and decision.

688.2 billion The sum will be used to finance the program developed for the implementation of these works, as well as to attract credit and grant funds from international financial institutions in the amount of 108.7 million US dollars[4].

In addition, on December 26, 2016, the law "On social services for the elderly, disabled people and other categories of citizens with social needs"was adopted.

The essence of this law is aimed at improving the legal framework of social services provided to needy categories of the population, determining the general requirements and main directions of providing social services, as well as increasing the role of state and non-governmental organizations in this area, defining the basic concepts in the social protection system, within which it is provided that they should take legal, economic, psychological, educational, medical, rehabilitation and other measures to create opportunities to participate in the life of society along with other citizens and independently meet their normal life needs.

The guarantee of protection of the population of low-income strata in need of social protection is defined as one of the priority tasks facing the leadership of the Republic today. In particular, this aspect was fully reflected in the state program for the implementation of the action strategy for the five priority areas of development of the Republic of Uzbekistan in the year of dialogue with the people and human 
CURRENT RESEARCH JOURNAL OF PEDAGOGICS 2(9): 22-25, September

2021 DOI: https://doi.org/10.37547/pedagogics-crjp-02-09-05

ISSN 2767-3278

(C)2021 Master Journals

\section{Crossref do) 11 Google}

Accepted 15th September, 2021 \& Published 20 ${ }^{\text {th }}$ September, 2021

interests in 2017-2021.

In order to increase the social activity of the elderly population and increase their status in society, the program is aimed at creating the necessary conditions for the participation of elderly citizens in the socio-political life of the country with the participation of the Nurani Foundation, the Mahalla Foundation, the women's family, the Family scientific and practical center, the Muslim Administration of Uzbekistan, the Council of Ministers of the Republic of Karakalpakstan, it is planned to ensure peace and tranquility in families and neighborhoods, as well as to increase the role of the younger generation in educating our people in the spirit of respect for centuries-old traditions. 200 million from the account of the executive funds for these events. it is planned to transfer the amount of funds[5].

In this direction, it is planned to increase the responsibility of employers and trade unions for supporting the older generation and expanding targeted social protection. In particular, in order to provide moral and material support to representatives of the older generation through collective agreements and agreements, the bund provided financial assistance to persons of 15 thousand retirement age before retirement and awarded them with valuable gifts, presented valuable gifts to 14 thousand employees on anniversaries, provided financial assistance to pensioners (former employees of enterprises). To carry out these works, the amount of employers ' funds amounted to 7 billion rubles. manats., 1 billion. from the account of trade union funds. the amount of funds transferred.

"In order to restore the health of the elderly population and more effectively organize the provision of high-quality medical and social services to them, measures are being taken in 2017 to strengthen the material and technical base of social institutions in the regions of the republic. For this purpose, a total of 49 billion rubles have been allocated from the state budget. manats. 312 million. the amount is credited[6].

It was planned to carry out a number of significant works on social protection of the population in need of protection, restoration of their health, provision of high-quality medical and social services. It is worth paying attention to the implementation of major projects in this regard, especially in target areas, remote areas.

In 2017, the state budget for the organization of free treatment of war and Labor Front veterans for 1941-1945, pensioners, the disabled, the elderly and other disadvantaged segments of the population of at least 35 thousand people in sanatorium-resort institutions amounted to 18 billion manats at the expense of the state budget. the amount of funds transferred.

In 2017 alone, it was planned to provide at least 10 thousand disabled and lonely elderly people with prosthetic and orthopedic products and technical means of rehabilitation on a free basis in order to increase the effectiveness of rehabilitation measures to support disabled people by providing them with prosthetic and orthopedic means, rehabilitation techniques and auxiliary means free of charge, as well as to return them to society. Budgetary and executive funds for the implementation of works in this direction amounted to 2.5 billion manats. the amount of funds transferred.

A number of works are being carried out in the field of further development and improvement of the system of providing medical and social assistance to pensioners, the disabled, the elderly, and other categories of the population in need in order to ensure a full life. In particular, the decision of President Sh. Mirziyoyev "On measures to further improve the provision of medicines and medical products to the population" dated October 31, 2016, pp-2647 is an important guideline in expanding the scope of 
CURRENT RESEARCH JOURNAL OF PEDAGOGICS 2(9): 22-25, September

2021 DOI: https://doi.org/10.37547/pedagogics-crjp-02-09-05

ISSN 2767-3278

(C)2021 Master Journals

Crossref dof 81 Google

Accepted 15th September, 2021 \& Published 20 ${ }^{\text {th }}$ September, 2021

work in this direction, increasing the level of providing our population with cheap and highquality medicines and medical products.

\section{Conclusion}

The issue of creating decent living conditions for the elderly, preserving their health is in the constant focus of attention of our state and society. The fact that the action strategy covers real measures related to comprehensive support for the elderly, war and Labor Front participants, people in need of social protection, as well as those who need the care of others, is an important factor in ensuring the implementation of the principle of "human interests above all" in our country.

\section{REFERENCES}

1. Speech of the Prime Minister of the Republic of Uzbekistan Shavkat Miromonovich Mirziyoev at the joint meeting of the legislative chamber and the Senate of the Oliy Majlis. // People's question, 9 September 2016.

2. Decree of the president of the Republic of Uzbekistan on measures for the further improvement of the activities of the "Nurani "fund for the social application of Veterans of Uzbekistan" on December 28, $2016 "$ pp-4906.

3. Decree of the president of the Republic of Uzbekistan on measures to ensure more effective organization of the process of acquisition of rights over land parcels and other immovable property as part of the South Caucasus pipeline expansion project more ... Collection of legislation of the Republic of Uzbekistan, 2017, Article 1, Article 10.

4. Support for the elderly and disabled is provided.

https://www.gazeta.uz/uz/2016/12/ 29 / elderly

5. Decree of the President of the Republic of Uzbekistan No. 4947 dated February 7, 2017 "On the strategy of actions for the further development of the Republic of Uzbekistan". - paragraph 214.

6. Decree of the President of the Republic of Uzbekistan No. 4947 dated February 7, 2017 "On the strategy of actions for the further development of the Republic of Uzbekistan"-paragraph 216. 